\title{
A new species of Hyphessobrycon Durbin (Characiformes: Characidae) from the rio Juruena basin, Central Brazil, with notes on $H$. loweae Costa \& Géry
}

\author{
Leonardo F. S. Ingenitoํㅜ, Flávio C. T. Lima² and Paulo A. Buckup ${ }^{3}$
}

A new species of Hyphessobrycon, H. peugeoti, is described from the middle portions of the rio Juruena drainage, upper rio Tapajós basin, Mato Grosso State, Brazil. It can be distinguished from all congeners, with the exception of $H$. loweae and $H$. heliacus, by a filamentous elongation of the dorsal fin and the approximately straight margin of the anal fin in adult males. It can be distinguished from both $H$. loweae and $H$. heliacus by an overall red coloration in life (vs. a golden coloration in life in the latter). Additionally, it can be distinguished from H. heliacus by the lack of chevron-like dark markings along the midline ( vs. presence of chevron-like dark-markings in H. heliacus), and from $H$. loweae by the presence of only five horizontal scale rows between the dorsal-fin origin and the lateral line (vs. 6-7 in H. loweae), and the higher number of branched anal-fin rays (21-24, modally 22, vs. 17-21, modally 20, in H. loweae). Additional meristic, morphometric, and distributional data are provided for Hyphessobrycon loweae, including its first record in the rio Araguaia/Tocantins basin. Comments on a putative monophyletic group including $H$. peugeoti, $H$. loweae, $H$. heliacus, H. elachys, and $H$. moniliger are presented.

Uma espécie nova de Hyphessobrycon, H. peugeoti, é descrita do trecho médio da drenagem do rio Juruena, bacia do alto rio Tapajós, estado de Mato Grosso, Brasil. Ela difere de todas as congêneres, com exceção de H. loweae e H. heliacus, pelo alongamento em forma de filamento da nadadeira dorsal e pela margem aproximadamente reta da nadadeira anal em machos adultos. Ela difere de $H$. loweae e $H$. heliacus por possuir coloração geral vermelha em vida ( $v s$. colorido dourado em vida em $H$. loweae e $H$. heliacus). Além disto, a espécie nova difere de $H$. heliacus por não possuir marcas em forma de divisas ao longo da linha média do corpo (vs. marcas em forma de divisas presentes em H. heliacus), e de $H$. loweae por possuir apenas cinco séries de escamas horizontais entre a origem da nadadeira dorsal e a linha lateral ( $v s .6-7 \mathrm{em} H$. loweae) e por possuir elevado número de raios ramificados na nadadeira anal (21-24, moda 22, vs. 17-21, moda $20 \mathrm{em} \mathrm{H}$. loweae). Dados merísticos, morfométricos e de distribuição geográfica adicionais são fornecidos para $H$. loweae, incluindo os primeiros registros da espécie na bacia do rio Tocantins-Araguaia. Discute-se um grupo presumidamente monofilético que inclui H. peugeoti, H. loweae, H. heliacus, H. elachys e H. moniliger.

Key words: Filamentous dorsal-fin, Hyphessobrycon elachys, Hyphessobrycon heliacus, Rio Tapajós basin, Rio Tocantins basin, Sexual dimorphism.

\section{Introduction}

As currently delimited, Hyphessobrycon Durbin is one of the most species-rich genera in the family Characidae, comprising 125 species currently recognized as valid (Almirón et al., 2004; 2006; Bertaco \& Carvalho, 2005; Bertaco \& Malabarba, 2005; Bertaco et al., 2007; Carvalho \& Bertaco,
2006; Carvalho et al., 2008; García-Alzate \& Román-Valencia, 2008; García-Alzate et al., 2008a, b; 2010a,b, c; Hein, 2009; Lima et al., 2003; Lima \& Moreira, 2003; Lucena, 2003; Malabarba et al., 2012; Menezes \& Weitzman, 2009; Miquelarena \& López, 2006, 2010; Zanata \& Camelier, 2010; Zarske \& Géry, 2004, 2006; Zarske et al., 2006; Zarske, 2008). As pointed out by several authors, most notably by Weitzman

${ }^{1}$ Universidade Federal do Espírito Santo, Programa de Pós-Graduação em Biodiversidade Tropical, Centro Universitário Norte do Espírito Santo, Departamento de Ciências Agrárias e Biológicas, Sala 15, Rodovia BR-101 Norte, km 60, $29932-540$ São Mateus, ES, Brazil. 1fsi@uol.com.br

${ }^{2}$ Museu de Zoologia da Universidade Estadual de Campinas “Adão José Cardoso”, Caixa Postal 6109, 13083-970 Campinas, SP, Brazil. fctlima@gmail.com

${ }^{3}$ Universidade Federal do Rio de Janeiro, Museu Nacional, Departamento de Vertebrados, Quinta da Boa Vista, 20940-040 Rio de Janeiro, RJ, Brazil.buckup@acd.ufrj.br 
\& Fink (1983) and Weitzman \& Palmer (1997), the genus Hyphessobrycon does not constitute a monophyletic unit. A recent comprehensive phylogenetic analysis of the family Characidae suggests that, as currently understood, Hyphessobrycon is a polyphyletic taxon, with some species forming a monophyletic clade with Astyanax Baird \& Girard and related genera, while the bulk of the species assigned to the genus are intermingled with species of Hemigrammus Gill, Pristella Eigenmann, Thayeria Eigenmann, Paracheirodon Géry, and Hasemania Ellis (Mirande, 2010). The type species of Hemigrammus, He. unilineatus (Gill), seems to be closely related to species of the "rosy-tetra" clade of Hyphessobrycon, which includes the type species of Hyphessobrycon, Hy. compressus (Meek) (Weitzman \& Palmer, 1997: 225-226, 237). Thus, Hyphessobrycon may be a putative synonym of Hemigrammus (Mirande, 2010: 509). Further studies on the systematics of the species currently assigned to Hyphessobrycon and related genera are still necessary to clarify this issue. We follow the traditional limits of Hyphessobrycon (sensu Eigenmann, 1918) until such studies become available.

Collecting activities undertaken in the last few years in the rio Juruena (which along with the rio Teles Pires, forms the rio Tapajós) revealed a distinctive pretty Hyphessobrycon species with an overall reddish color pattern and a greatly elongated dorsal fin in adult males. This species closely resembles and is putatively related to $H$. loweae Costa \& Géry, described from the upper rio Xingu basin in Brazil. The purpose of the present study is to describe the new species, and to provide additional information on the diagnosis and distribution of $H$. loweae.

\section{Material and Methods}

Counts and measurements were taken according to Fink \& Weitzman (1974) and Menezes \& Weitzman (1990), except for the number of horizontal scale rows below the lateral line, which were counted to the pelvic-fin insertion. The number of horizontal scale rows between dorsal-fin origin and lateral line does not include scales of the median predorsal series situated just anterior to first dorsal-fin ray. In the descriptions, the frequency of each count is given in parentheses after the corresponding count. An asterisk indicates counts of the holotype. Counts of supraneurals, vertebrae, procurrent caudal-fin rays, unbranched dorsal- and anal-fin rays, branchiostegal rays, gill-rakers, and dentary teeth were taken from cleared and stained paratypes (c\&s), prepared according to Taylor \& van Dyke (1985). Vertebrae of the Weberian apparatus were counted as four elements and included in the vertebral counts, and the compound caudal centrum (preural $1+$ ural 1; Fink \& Fink, 1981) was counted as a single element. Institutional abbreviations are as follows: ANSP, Academy of Natural Sciences of Philadelphia, Philadelphia; MNRJ, Museu Nacional, Universidade Federal do Rio de Janeiro, Rio de Janeiro; MZUSP, Museu de Zoologia da Universidade de São Paulo, São Paulo; and ZUEC, Museu de Zoologia da
Universidade Estadual de Campinas "Adão José Cardoso", Campinas. Specimens are grouped by state and hydrographic drainage and ordered from North to South in the lists of examined specimens.

\section{Results}

\section{Hyphessobrycon peugeoti, new species} Figs. 1-4

Holotype. MNRJ 38988, 30.5 mm SL, male, Brazil, Mato Grosso State, Cotriguaçu, stream at fazenda São Nicolau, left margin tributary of rio Juruena, 0952'02.3”'S 58¹6’45.6”W, 5 May 2006, P. A. Buckup, L. F. S. Ingenito, I. L. Assumpção \& G. A. Araújo.

Paratypes. Brazil. Mato Grosso State: MNRJ 29503, 1, male, $28.6 \mathrm{~mm}$ SL, Cotriguaçu, stream at fazenda São Nicolau, left margin tributary of rio Juruena, 0951'33.4”S 58 15'19.8”W, 5 May 2006, P. A. Buckup, L. F. S. Ingenito, I. L. Assumpção \& G. A. Araújo. MNRJ 29609, 11, 9 males (1 c\&s, $27.3 \mathrm{~mm} \mathrm{SL}$ ) and 2 females, 22.6-28.9 mm SL, Cotriguaçu, small stream at fazenda São Nicolau, left margin tributary of rio Juruena, 0951'42.8'S 58 14'55.3' 'W, 6 May 2006, P. A. Buckup, L. F. S. Ingenito, I. L. Assumpção \& F. B. Freitas. MNRJ 29521, 2, males, 29.7 and $30.8 \mathrm{~mm} \mathrm{SL}$, collected with the holotype. MZUSP 77734, 67, 6 males, 61 unsexed juveniles, 12.6-31.7 mm SL (6 c\&s, 15.6-21.1 mm SL); ANSP 190999, 2, 1 male, 1 female, 22.5 and $31.7 \mathrm{~mm} \mathrm{SL}$; ZUEC 6362, 2, 1 male, 1 female, 20.5 and $30.2 \mathrm{~mm}$ SL, Juruena, rio Juruena, $c a$. $1 \mathrm{~km}$ below mouth of rio Arinos, 10²3'42”S, 58¹9'58'W, 25-26 Jul 1997, F. A. Machado, C. M. C. Leite, M. F. Catarino \& C. H. Melo.

Diagnosis. Hyphessobrycon peugeoti n. sp. can be distinguished from all congeners, with the exception of $H$. elachys Weitzman, H. heliacus Moreira, Landim \& Costa, and $H$. loweae, by a conspicuously elongated and filamentous dorsal fin in mature males ( $v s$. dorsal and pelvic fins, when elongated, never filamentous). Hyphessobrycon peugeoti can be distinguished from these species by its overall red color in life (vs. a general clear/silvery color in H. elachys, and golden color in H. heliacus and H. loweae). Additionally, H. peugeoti can be distinguished from $H$. elachys by possessing an anal fin with a straight margin in mature males ( $v s$. a distinctly rounded anal-fin lobe present in $H$. elachys mature males); from $H$. heliacus it differs by possessing shorter pelvic-fins in fully mature males, reaching only the second anal-fin branched ray (vs. pelvic-fins filamentous, reaching up to the sixth anal-fin branched ray in $H$. heliacus), and by lacking chevron-like dark markings along the midline (vs. chevron-like dark markings along the midline present in $H$. heliacus); from $H$. loweae it differs by possessing a lower number of horizontal scale rows between the dorsal-fin origin and the lateral line (5 vs.6-7 in H. loweae), and by possessing a higher number of branched anal-fin rays (21-24, modally 22, vs. 17-21, modally 20 in H. loweae).

Description. Morphometric data in Table 1. Body compressed, moderately deep, greatest body depth slightly anterior to dorsal-fin origin. Dorsal profile of head convex from upper lip to vertical through posterior nostril; straight to slightly convex 


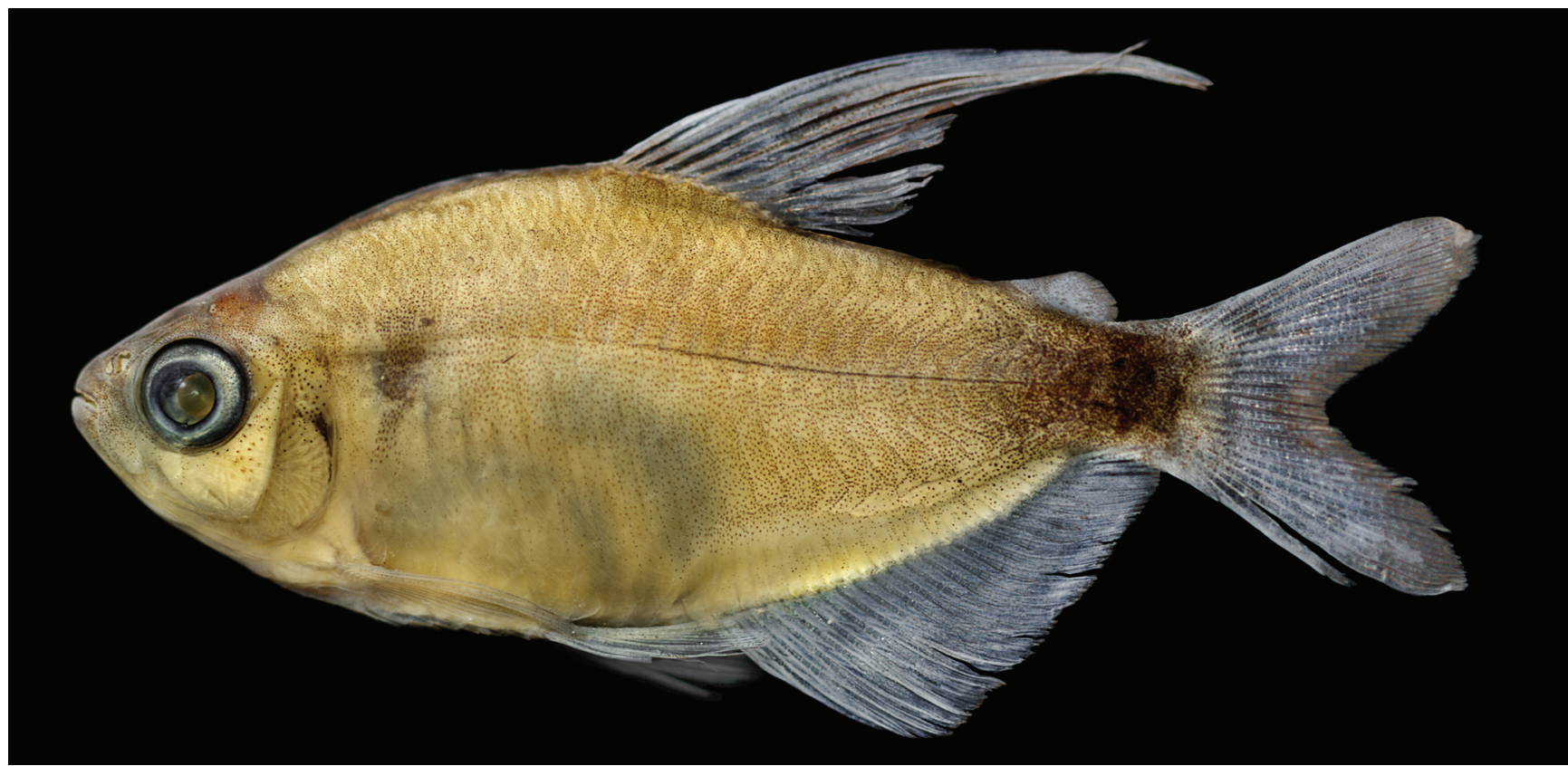

Fig. 1. Hyphessobrycon peugeoti new species, holotype, MNRJ 38988, 38.5 mm SL, male, Brazil, Mato Grosso State, Cotriguaçu, tributary of rio Juruena.

from nostril to tip of supraoccipital spine. Predorsal profile of body slightly convex, dorsal-fin base straight to slightly convex, posteroventrally inclined. Body profile straight to slightly concave from dorsal-fin base to adipose fin; concave between latter point and origin of anteriormost procurrent caudal-fin ray. Ventral profile of head and body slightly convex to pelvic-fin origin; slightly concave from that point to analfin origin; straight to slightly convex, posteriorly slanted along anal-fin base; slightly concave along caudal peduncle.
Mouth terminal, anteroventral end of dentary protruding slightly. Maxilla slightly surpassing vertical line through anterior margin of orbit. Premaxillary teeth in two rows. Outer row with three $\left(12^{*}\right)$ or four (2) tetra- to hexacuspid teeth. Inner row with five $\left(12^{*}\right)$ or six (2) hexato heptacuspid teeth. Maxilla with two $\left(10^{*}\right)$ or three (4) tetra- to pentacuspid teeth. Dentary with five large pentato heptacuspid teeth followed by three to six smaller unito tricuspid teeth (Fig. 3).

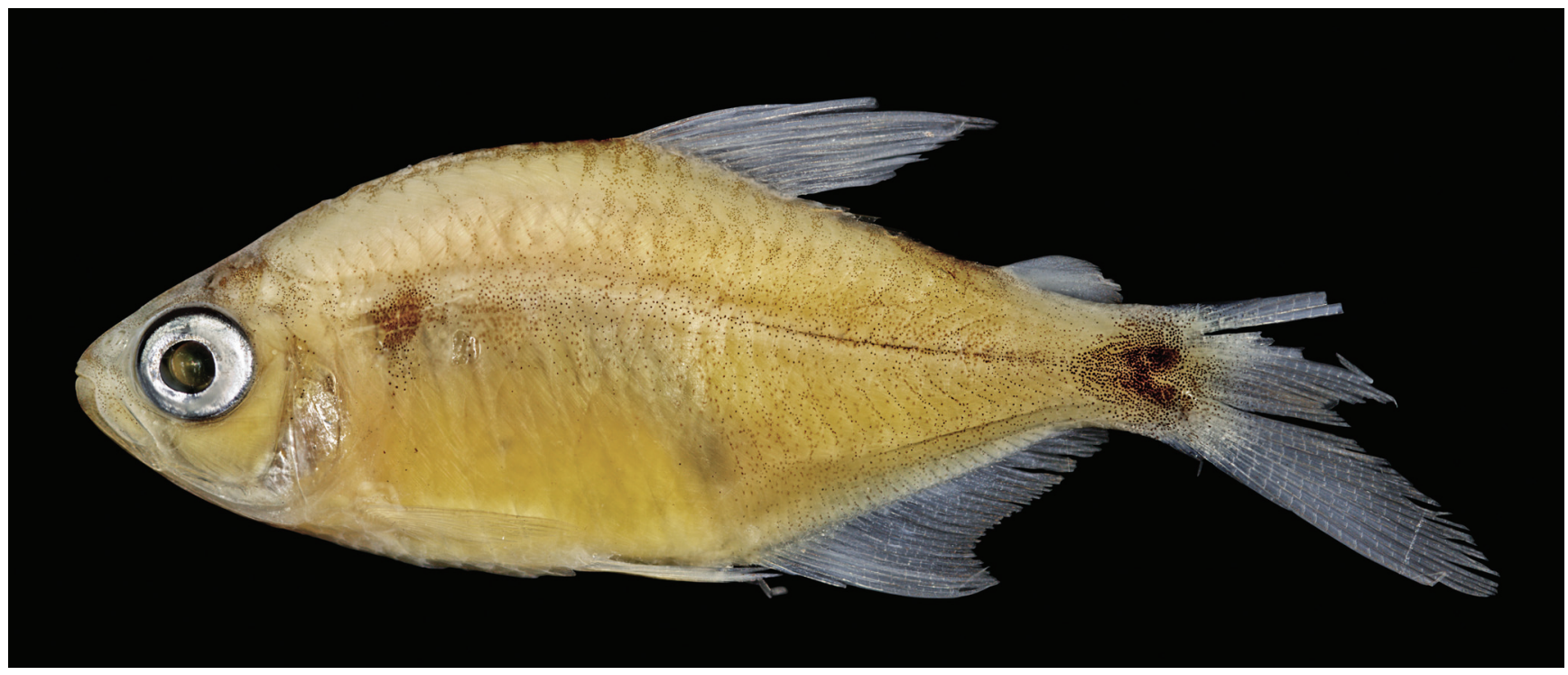

Fig. 2. Hyphessobrycon peugeoti new species, paratype, MZUSP 77734, 25.9 mm SL, female, Brazil, Mato Grosso State, rio Juruena. 


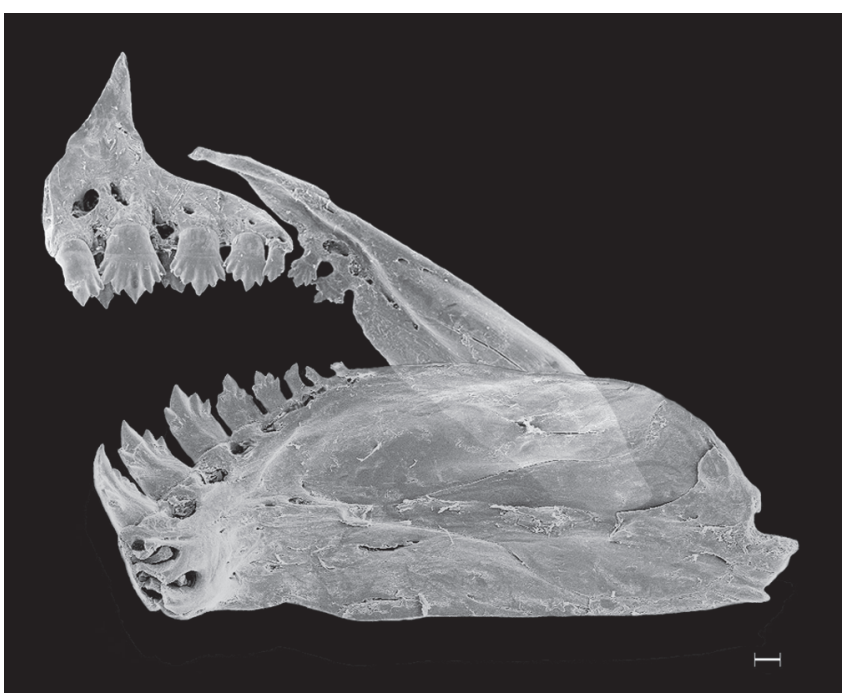

Fig. 3. Hyphessobrycon peugeoti new species, paratype, MNRJ 29609, $27.3 \mathrm{~mm}$ SL: left premaxillary, dentary, and maxillary bones in mesial view. Scale bar: $100 \mu \mathrm{m}$.

Scales cycloid, with four to seven radii; circuli strongly marked anteriorly, but absent distally ("Hemigrammus type" of Cockerell, 1915). Lateral line incompletely pored, with four (1), five (4), six (3), seven ( $8^{*}$ ), or eight (4) perforated scales. Lateral-series scales including perforated scales 26(1), 29(1), $30(1), 31(2), 32\left(5^{*}\right), 33(1)$, or 34(3). Horizontal scale rows between dorsal-fin origin and lateral line five $\left(22^{*}\right)$, not including half scale of predorsal series situated just anterior to first dorsal-fin ray. Horizontal scale rows between lateral line and pelvic-fin origin four $\left(21^{*}\right)$. Scales around caudal peduncle 11(3) or 12(10*). Single row of three to five scales covering base of anteriormost anal-fin rays.

Dorsal-fin rays ii,9, not including small ossification anterior to first unbranched ray, discernible only in c\&s specimens, present in five out of seven c\&s specimens. Dorsal-fin origin at mid-body. Base of last dorsal-fin ray at vertical through anal-fin origin. First dorsal-fin pterygiophore inserting behind neural spine of ninth (7) vertebra. Dorsal-fin very elongated in mature males specimens, reaching area between adiposefin origin and first fourth of caudal fin when depressed; first to third branched dorsal-fin rays longest. Adipose fin present. Anal-fin rays iv (19*) or v (1), 21(5), 22(11*), 23(6), or 24(1). First anal-fin pterygiophore inserted behind hemal spine of sixteenth (6), or seventeenth (1) vertebra. Anal-fin margin slightly convex in males, with almost all rays thick, curved posteriorly; first to fifth branched rays slightly longer than remaining rays, decreasing in length gradually, not forming lobe. Anal-fin margin anteriorly pointed in females, with fourth to twelfth rays more elongate, forming discrete lobe, remaining rays gradually decreasing in length posteriorly. Pectoral-fin rays i,9(2), 10(15), 11(6), or 12(1); tip of fin generally surpassing pelvic-fin origin. Pelvic-fin rays i,7; tip of fin reaching insertion of first to fourth anal-fin rays. Caudal-fin rays i,16(1) or 17( $3 *)$,i. Caudal fin forked; upper and lower lobes similar in size. First gill arch with seven epibranchial, nine ceratobranchial, three hypobranchial gill-rakers (1). Four branchiostegal rays (1). Vertebrae 32(4), or 33(3). Supraneurals four (4), or five (2).

Color in alcohol. Ground color pale to light yellowish. Guanine pigmentation present on opercular and infraorbital series, and on few scales in some specimens. Body covered by scattered dark chromatophores, except at ventral regions of head and abdomen, which are clear. Dorsal surface of head and body, from snout to caudal fin, presenting dense concentration of dark chromatophores. Humeral region with vertically elongated, roughly rectangular dark blotch, tapering ventrally, at level of second and fourth lateral line scales. Blotch one and half scales wide, three to three and half scales high. Narrow midlateral stripe formed by chromatophores at myosepta between hypaxial and epaxial bundles of muscles, more conspicuous posteriorly to dorsal-fin base. Dark chromatophores distributed along myomeres junctions forming chevron marks, except at region immediately above anal-fin base, where dark chromatophores are uniformly scattered. Caudal peduncle blotch black, widely expanded in larger specimens, forming broad rectangular blotch occupying entire caudal peduncle surface. Dorsal, adipose, and caudal fins with considerable amount of dark chromatophores, imparting overall dark coloration to these fins. Dark chromatophores of dorsal fin more concentrated over its apical portion. Pectoral and pelvic fins hyaline, with few, scattered dark chromatophores. Anal fin hyaline, with some scattered dark chromatophores on interradial membranes.

Color in life. Based on photograph of freshly collected holotype (Fig. 4). Top of head and dorsal portion of body dark red. Lateral and ventral portions of body silvery, suffused with red

Table 1. Morphometric data of Hyphessobrycon peugeoti new species from rio Juruena drainage, based on holotype (MNRJ 38988) and paratypes (MNRJ 29503, 1 ex.; MNRJ 29521, 2 ex.; MNRJ 29609, 10 ex; MZUSP 77134, 8 ex.; ANSP 190999, 1 ex.; ZUEC 6362, 1 ex). $\mathrm{N}=$ sample size; $\mathrm{SD}=$ Standard deviation. Range includes holotype.

\begin{tabular}{lcccccc}
\hline & $\mathrm{N}$ & Holotype & Low & High Mean & SD \\
\hline Standard Length (mm) & 24 & 30.5 & 22.6 & 31.7 & - & - \\
& Percents of & Standard Length & & & \\
Head length & 24 & 26.6 & 25.6 & 30.5 & 27.6 & 1.1 \\
Depth at dorsal-fin origin & 24 & 42.0 & 30.2 & 42.0 & 36.0 & 3.0 \\
Snout to dorsal-fin origin & 24 & 51.1 & 48.1 & 55.7 & 51.8 & 1.9 \\
Snout to pelvic-fin origin & 24 & 47.5 & 44.0 & 50.4 & 47.6 & 1.6 \\
Snout to anal-fin origin & 24 & 61.3 & 58.6 & 66.8 & 61.6 & 1.8 \\
Dorsal-fin height of males & 16 & 51.8 & 30.3 & 51.8 & 38.2 & 5.3 \\
Dorsal-fin height of females & 8 & - & 31.4 & 35.1 & 33.6 & 1.2 \\
Pectoral-fin length & 24 & 23.3 & 17.7 & 23.5 & 21.6 & 1.2 \\
Pelvic-fin length & 24 & 21.1 & 16.5 & 21.8 & 19.6 & 1.4 \\
Anal-fin base length & 24 & 36.1 & 27.8 & 36.1 & 32.0 & 2.3 \\
Caudal peduncle length & 24 & 11.1 & 9.6 & 14.9 & 11.6 & 1.3 \\
Caudal peduncle depth & 24 & 10.8 & 8.3 & 11.2 & 9.7 & 0.8 \\
& Percents of Head Length & & & \\
Snout length & 24 & 23.5 & 18.9 & 26.2 & 22.5 & 1.5 \\
Orbital diameter & 24 & 42.0 & 34.5 & 47.7 & 41.3 & 4.1 \\
Interorbital width & 24 & 34.6 & 28.0 & 36.7 & 32.2 & 1.9 \\
Upper jaw length & 24 & 40.7 & 33.8 & 43.0 & 39.3 & 2.6 \\
\hline
\end{tabular}




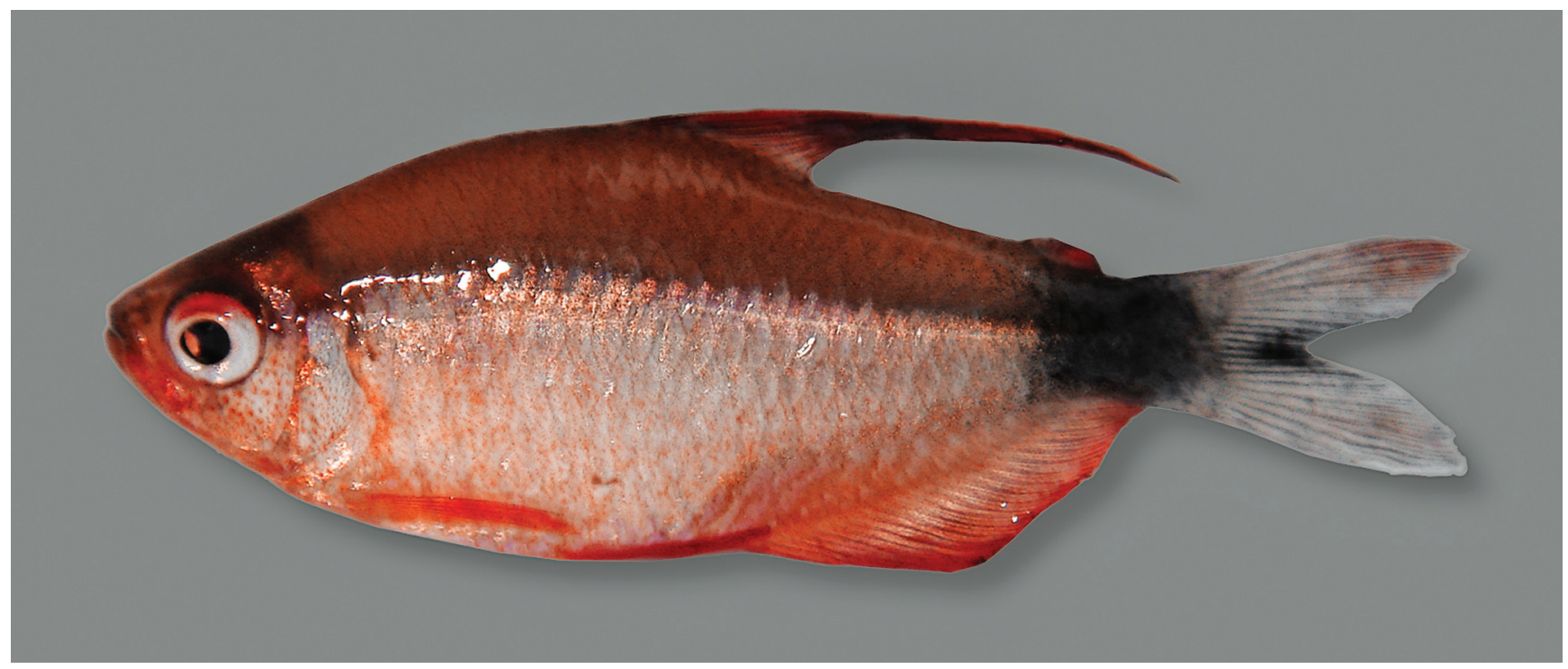

Fig. 4. Hyphessobrycon peugeoti, new species, holotype, MNRJ 38988, 38.5 mm SL, male, Brazil, Mato Grosso State, Cotriguaçu, tributary of rio Juruena, immediately before fixation.

chromatophores which impart overall carmine red coloration. Dorsal, pectoral, pelvic, and anal fins carmine red. Caudal peduncle blotch dark. Caudal fin hyaline, with some diffuse dark and reddish pigmentation. Female coloration in life not recorded.

Sexual dimorphism. Adult males of Hyphessobrycon peugeoti are readily discernible from females by presenting an elongation of the dorsal fin that becomes filamentous, reaching, when depressed, the caudal-fin basis in fully grown specimens, and an approximately straight margin, and thickened rays in the anal fin. This fin morphology contrasts with the normally developed dorsal fin and the lobed anal fin of females (compare Figs. 1 and 2). The caudal peduncle blotch is also more developed in adult males. These dimorphic features are also found in $H$. heliacus and H. loweae. Fin hooks, a common feature of mature characid males (Malabarba \& Weitzman, 2003) are absent (see Discussion, below).

Habitat and ecological notes. Specimens of Hyphessobrycon peugeoti was collected in shallow areas (less than $1 \mathrm{~m}$ deep) in the early dry season. The type locality of $H$. peugeoti was a swampy deforested area, alongside a detour of road MT-208 (old road BR-80) immediately downstream from a preserved tract of native forest; the water flow was choked with grasses and small shrubs. Sample MNRJ 29609 was collected downstream where the stream crossed the dry and muddy bottom of a dam that was burst open by heavy rains about two months earlier. The single specimen MNRJ 29503 was collected in a flowing stream with sandy bottom, transparent water, and poorly-developed aquatic vegetation. Paratypes ANSP 190999, MZUSP 77734, and ZUEC 6362 were collected in a flooded area adjacent to the rio Juruena.
Distribution. Hyphessobrycon peugeoti is only known from tributaries of the middle rio Juruena, upper rio Tapajós basin, Mato Grosso State, Brazil (Fig. 5).

Etymology. Hyphessobrycon peugeoti is patronymic to the Peugeot family, who invented the Peugeot pepper mill mechanism in 1842 and whose manufacturing business led to the establishment of a carbon sink reforestation project in the fazenda São Nicolau, in central Brazil, and eventually to the discovery of this new species.

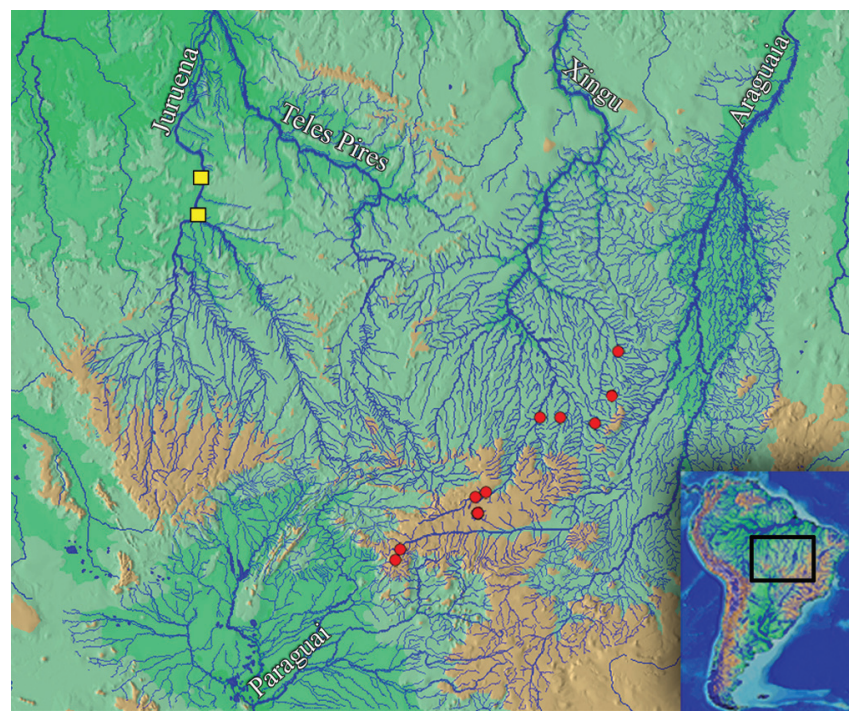

Fig. 5. Map of central South America, showing known localities of Hyphessobrycon peugeoti n. sp. (yellow squares) and $H$. loweae (red dots). The northern square includes the typelocality and two other localities of Hyphessobrycon peugeoti. Inset depicts the area of South America displayed in the map. 


\section{Hyphessobrycon loweae Costa \& Géry, 1994} Figs. 6-9

Hyphessobrycon sp. "long dorsal": Lowe-McConnell, 1991: 68 (Brazil, Mato Grosso State, upper rio Xingu; "Lago do Leo" and "Corrego do Gato", rio Suiá-Missu drainage, rio Xingu basin).

Hyphessobrycon loweae Costa \& Géry, 1994: 71-73, fig. 1 (description; type-locality "Brazil: Estado de Mato Grosso, córrego Xavante, a tributary of rio Culuene, rio Xingú basin, $40 \mathrm{~km} \mathrm{~S}$ of Paranatinga, $15^{\circ} 01^{\prime} \mathrm{S}, 54^{\circ} 03^{\prime} \mathrm{W}$ '; corrected coordinates of type locality approximately $\left.14^{\circ} 43^{\prime} \mathrm{S} 54^{\circ} 04^{\prime} \mathrm{W}\right)$.

Diagnosis. Hyphessobrycon loweae can be distinguished from all congeners, with the exception of $H$. elachys, $H$. heliacus, and $H$. peugeoti, by the conspicuously elongated and filamentous dorsal fin in mature males ( $v s$. dorsal and pelvic fins, when elongated, never filamentous). Hyphessobrycon loweae can be distinguished from $H$. elachys and $H$. peugeoti by its overall golden color in life ( $v s$. a general clear/silvery color in $H$. elachys, and reddish color in $H$. peugeoti). Hyphessobrycon loweae can be distinguished from $H$. heliacus by the shorter pelvic-fins in fully mature males, reaching only the first anal-fin branched ray ( $v s$. pelvic-fins filamentous, reaching up to the sixth anal-fin branched ray in H. heliacus), and by lacking chevron-like dark markings along the midline ( $v s$. chevron-like dark markings along the midline present in $H$. heliacus). Additionally, $H$. loweae can be distinguished from $H$. elachys by possessing an anal fin with a straight margin in mature males ( $v s$. a distinctly rounded anal-fin lobe present in $H$. elachys mature males); and from $H$. peugeoti by possessing a higher number of horizontal scale rows between the dorsal-fin origin and the lateral line (6-7, 5 vs. 5 in $\mathrm{H}$. peugeoti), and by possessing a lower number of branched anal-fin rays (17-21, modally $20, v s .21-24$, modally 22 in H. peugeoti).

Summary of meristic data. Lateral line incompletely pored, five (2), six (5), seven (22), eight (13), nine (3), or 10(1) perforated scales. Lateral series scales including perforated scales 27(1), 28(2), 30(1), 31(5), 32(10), 33(11), 34(10), 35(4), or $37(1)$. Horizontal scale rows between dorsal-fin origin and lateral line six (39), or seven (7), not including half scale of predorsal series situated just anterior to first dorsal-fin ray. Horizontal scale rows between lateral line and pelvic-fin origin three (1), four (42), or five (1). Scales around caudal peduncle 12(6), 13(14), 14(17), or 15(5). Dorsal-fin rays ii, 8(11), or 9(37). Anal-fin rays iv, 17(1), 18(8), 19(27), 20(9), or 21(3). Pectoralfin rays i, 9(6), 10(20), 11(20), or 12(2). Pelvic-fin rays i, 6(13), or 7(35). First gill arch with two (5), three (1) epibranchial, eight (1), nine (5), or 10(1) ceratobranchial, and five (5), or six (2) hypobranchial gill-rakers. Vertebrae 31(2), 32(3), or 33(2). Supraneurals four (6). Morphometric data in Table 2.

Color in alcohol. Ground color pale to light yellowish. Guanine pigmentation present on opercular and infraorbital series, and on flank scales of most specimens, except those stored for long time in formalin. Body covered by scattered dark chromatophores, except at ventral regions of head and abdomen, which are clear. Dorsal surface of head and body, from snout to caudal fin, presenting dense concentration of dark chromatophores, mostly on distal portion of scales. Humeral region with vertically elongated, roughly rectangular dark blotch, tapering ventrally, at level of second and fourth lateral line scales. Blotch one and a half scales wide, four to

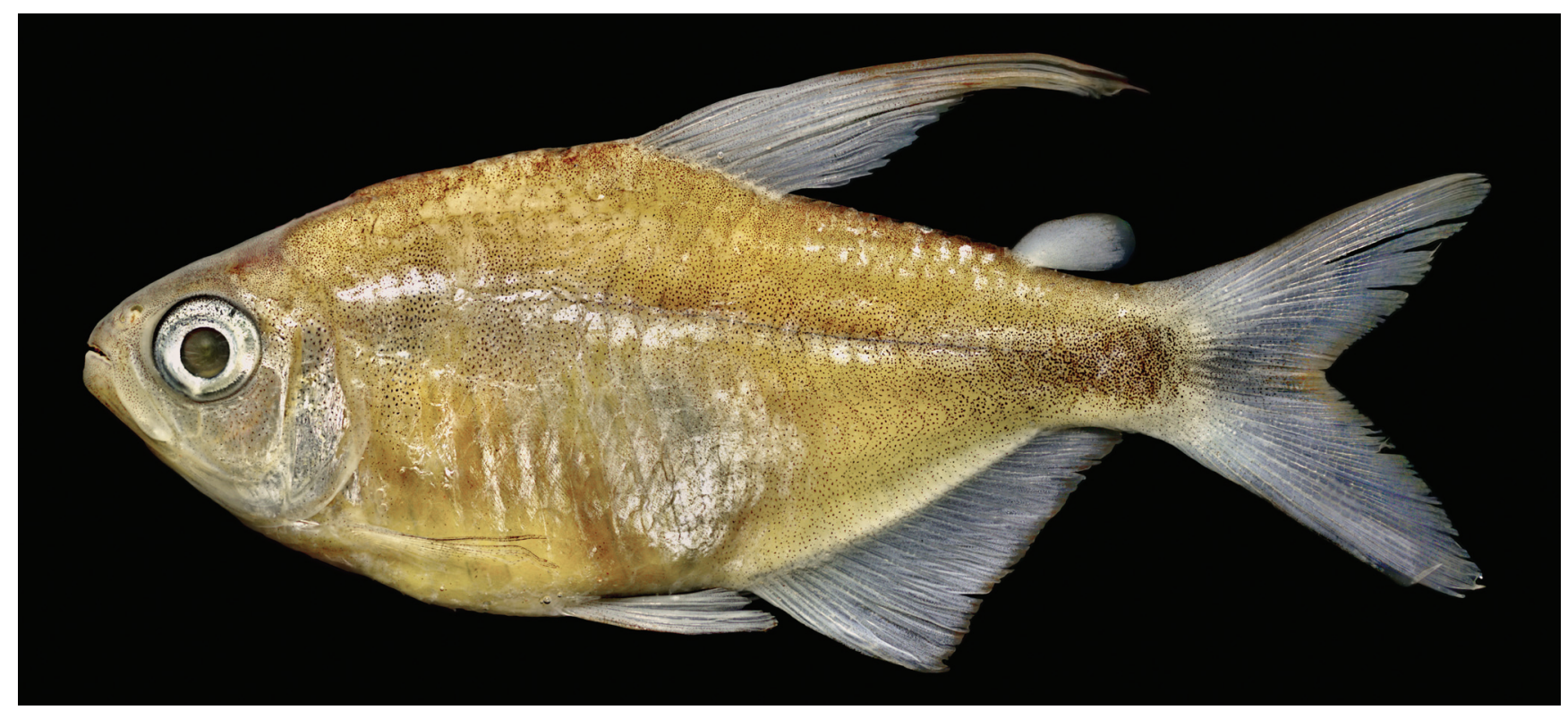

Fig. 6. Hyphessobrycon loweae, MZUSP 102816, $33.4 \mathrm{~mm}$ SL, topotype, male, Brazil, Mato Grosso State, ribeirão Xavante (rio Xingu basin). 


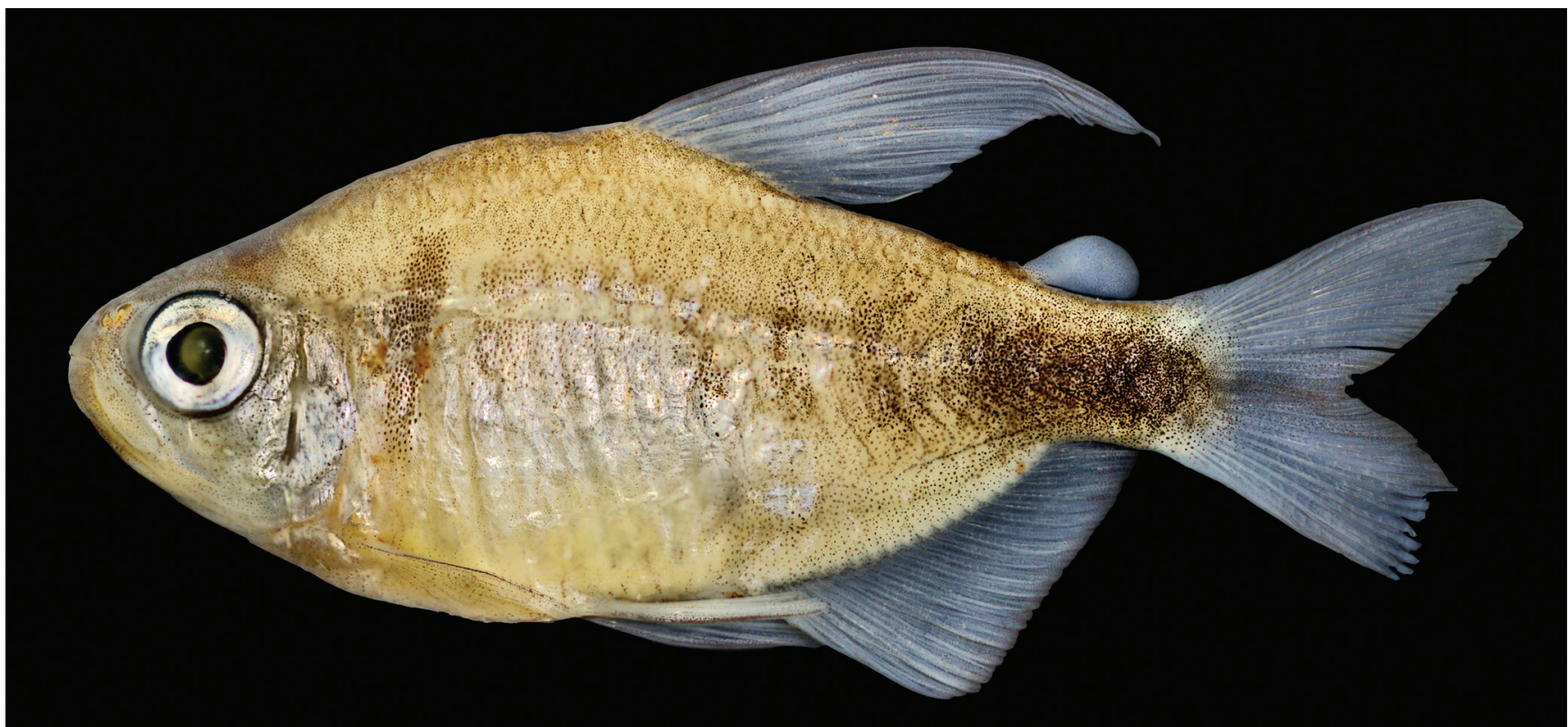

Fig. 7. Hyphessobrycon loweae, MZUSP 101404, 29.0 mm SL, male, Brazil, Mato Grosso State, rio das Mortes (rio Araguaia/ Tocantins basin).

five scales high. Narrow midlateral stripe formed by chromatophores at myosepta between hypaxial and epaxial bundles of muscles, more conspicuous posteriorly to dorsalfin base. Scattered dark chromatophores scattered across flanks forming ill-defined, broad dark lateral band. Dark chromatophores distributed along myomere junctions, forming thin, angled lines (chevron marks). Caudal peduncle blotch black, variously developed, more developed in males, varying from occupying most of caudal peduncle surface to concentrated on its middle portion, extending across 5-9 last scales of lateral line. Some adult males with blurred, curved dark vertical bars at flanks. Caudal fin with variously developed dark pigmentation on middle caudal-fin rays of adult males, varying from some pigmentation on middle caudal-fin rays to relatively well-defined stripe. Remaining fins clear, with scattered dark chromatophores. Dark chromatophores of dorsal fin more concentrated over its apical portion. Pectoral and pelvic fins hyaline, with few, scattered

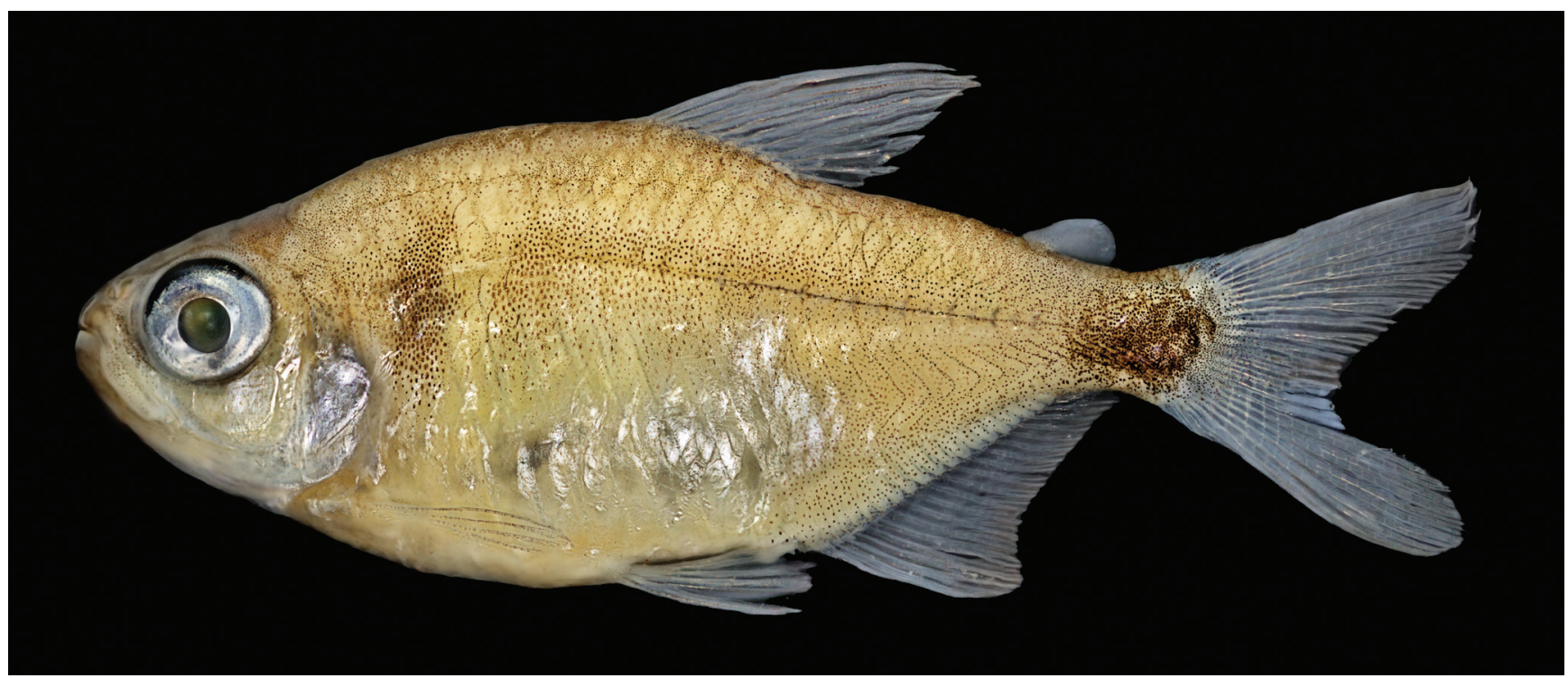

Fig. 8. Hyphessobrycon loweae, MZUSP 101404, $28.1 \mathrm{~mm}$ SL, female, Brazil, Mato Grosso State, rio das Mortes (rio Araguaia/ Tocantins basin). 
Table 2. Morphometric data of Hyphessobrycon loweae, based on the paratypes (MZUSP 45749, 2 x.; MZUSP 45750, 1 ex.; MZUSP 45751, 1 ex); and on non-type specimens (MZUSP 97435, 1 ex.; MZUSP 95611, 3 ex.; MZUSP 101404, 13 ex.; MZUSP 97693, 1 ex.; MZUSP 102816, 14 ex.; MZUSP 97846, 10 ex.; and MZUSP 102817, 2 ex.). $\mathrm{N}=$ sample size; $\mathrm{SD}=$ Standard deviation. Range includes paratypes.

\begin{tabular}{lccccc}
\hline & $\mathrm{N}$ & Low & High & Mean & SD \\
\hline Standard Length (mm) & 48 & 22.1 & 34.8 & - & - \\
\multicolumn{7}{c}{ Percents of Standard Length } \\
Head length & 48 & 25.6 & 30.4 & 28.2 & 1.1 \\
Depth at dorsal-fin origin & 48 & 33.1 & 48.0 & 38.5 & 3.1 \\
Snout to dorsal-fin origin & 48 & 50.0 & 55.2 & 52.6 & 1.2 \\
Snout to pelvic-fin origin & 47 & 45.1 & 52.7 & 49.1 & 1.7 \\
Snout to anal-fin origin & 48 & 57.6 & 68.0 & 63.4 & 2.1 \\
Dorsal-fin height of males & 25 & 35.8 & 61.0 & 46.2 & 6.2 \\
Dorsal-fin height of females & 21 & 27.5 & 37.2 & 31.4 & 2.7 \\
Pectoral-fin length & 48 & 18.8 & 26.0 & 21.8 & 1.5 \\
Pelvic-fin length & 48 & 17.8 & 24.1 & 20.8 & 1.6 \\
Anal-fin base length & 48 & 25.0 & 32.0 & 28.7 & 1.7 \\
Caudal peduncle length & 48 & 12.5 & 16.2 & 14.4 & 0.9 \\
Caudal peduncle depth & 48 & 7.6 & 16.0 & 10.5 & 1.5 \\
& Percents of Head Length & & \\
Snout length & 48 & 20.5 & 28.8 & 24.6 & 1.7 \\
Orbital diameter & 48 & 35.8 & 44.4 & 39.8 & 1.8 \\
Interorbital width & 48 & 26.0 & 39.1 & 30.4 & 2.6 \\
Upper jaw length & 48 & 39.7 & 47.8 & 44.4 & 2.1 \\
\hline
\end{tabular}

dark chromatophores. Anal fin hyaline, with some scattered dark chromatophores over its interradial membranes.

Color in life. Based on photographs of two mature males (MZUSP 97435, one depicted in Fig. 9), and the holotype (Costa \& Géry, 1994: 72, fig. 1), and cursorial examination in the field of freshly collected specimens from lots MZUSP 97435 and MZUSP 95611 by the second author. Overall coloration (including all fins) golden-yellow; some specimens presenting a large amount of silvery pigmentation, apparently a consequence of infestation by trematodes ("brass-tetras"; $c f$. Géry \& Delage, 1963). Upper portion of eye red.

Sexual dimorphism. Hyphessobrycon loweae presents the same type of sexual dimorphism as observed in $H$. peugeoti, i.e., mature males with an elongated, filamentous dorsal fin, anal fin with all fin rays with approximately the same size and relatively enlarged, resulting into a straight fin margin, and a more developed caudal-fin blotch. As in Hyphessobrycon pengeoti, mature males of $H$. loweae lack fin hooks.

Habitat and ecological notes. Hyphessobrycon loweae inhabits streams with clear water, slow current and abundant submerged vegetation. This is the type of habitat found at the type locality, the córrego Xavante (C. R. Moreira, pers. comm.; Costa \& Géry, 1994), as well as at the upper rio das Mortes (J. L. Birindelli, pers. comm.) and tributaries of the rio Culuene at Gaúcha do Norte (F. C. T. L., pers. obs.). "Lago do Leo" at the rio Suiazinho, where some paratypes of Hyphessobrycon loweae were collected, is a small lake with dense aquatic vegetation (Lowe-McConnell, 1991: 71). Similarly to some congeners such as $H$. eques (Steindachner), H. micropterus (Eigenmann), and Hyphessobrycon negodagua Lima \& Gerhard (Lima \& Gerhard, 2001: 112-113), H. weitzmanorum Lima \& Moreira (Lima \& Moreira, 2003: 30), and $H$. bifasciatus Ellis (Lima et al., 2008), it appears that $H$. loweae favors streams and/or ponds with abundant submerged aquatic vegetation.

Distribution and biogeography. Hyphessobrycon loweae was originally described from tributaries of the rio Culuene and rio Suiá-Missú in the upper rio Xingu basin, Mato Grosso, Brazil. The species is herein recorded from the upper rio das Mortes, a tributary of the rio Araguaia-Tocantins basin (Fig. 5). The species is known from adjacent (less than $20 \mathrm{~km}$ apart) headwaters of the rio Culuene and rio das Mortes, and presumably may have been transposed across the water divide via stream capture events. Several fish species are known to occur in adjacent river systems across the southern tributaries of the Amazon basin flowing through the Brazilian shield, presumably due to river capture events resulting from neotectonic reactivation of ancient faults of the Transbrasiliano lineament, which transverses the region (Lima \& Ribeiro, 2011).

Remarks. Comparisons between Hyphessobrycon loweae specimens from the rio Culuene (rio Xingu basin) and rio das Mortes (rio Tocantins-Araguaia basin) did not reveal any features that might distinguish these different populations, and thus they are herein considered to represent a single species. The vertically-elongated, curved dark bars in the posterior portion of body (Fig. 7) are present in some mature male specimens from both the rio das Mortes (MZUSP 101404) as well as from the rio Culuene (MZUSP 95611) drainages.

Material examined. Brazil. Mato Grosso State: Rio Araguaia basin: MZUSP 97701, 22, 17.8-29.0 mm SL, Santo Antônio do Leste, tributary to rio das Mortes, near border between Santo Antônio do Leste and Riacho Suspiro, 1452'30"S, 5405'00"W. MZUSP 97889, 1, 25.7 mm SL, Santo Antônio do Leste, riacho Gailiro (rio das Mortes basin), road MT-130, 14 ${ }^{\circ} 53^{\prime} 34^{\prime \prime S}$, 5404'45"W. MZUSP 97693, 1, 34.8 mm SL, Campo Verde, rio das Mortes, road BR-070, 1540'22”S, 55¹7'53”W. MZUSP 101404, 47, 11.7-29.0 mm SL, Campo Verde, rio das Mortes, road Chapada dos Guimarães/Campo Verde, 15³0'20'S, 55¹3'38'W. Rio Xingu basin: MZUSP 45749, 2 paratypes, 21.6 and $21.9 \mathrm{~mm}$ SL, Querência, "Lago do Leo" (rio Suiaizinho drainage), ca. $12^{\circ} 43^{\prime} \mathrm{S}$ 51 ${ }^{\circ} 50^{\prime} \mathrm{W}$. MZUSP 45750, 1, paratype, $22.2 \mathrm{~mm}$ SL. MZUSP 45751, 2, paratypes, 21.0 and $23.0 \mathrm{~mm} \mathrm{SL}$, ribeirão Cascalheira, "córrego do Gato" (rio Suiaizinho drainage), ca. 12 ${ }^{\circ} 56^{\prime}$ 'S 51 ${ }^{\circ} 51^{\prime} \mathrm{W}$. MZUSP 95611, 14, 13.1-25.6 mm SL, Gaúcha do Norte, stream tributary of rio Culuene, at MT-020, 13³0'00'S 535'35”W. MZUSP 97435 227, 10 c\&s, 10.4-27.6 mm SL, Gaúcha do Norte, stream near

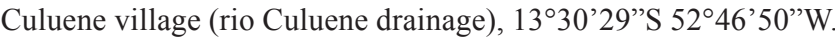
MZUSP 102817, 10, 22.4-25.5 mm SL, Canarana, stream tributary to ribeirão Água Limpa (tributary to rio Sete de Setembro), $5 \mathrm{~km} \mathrm{~S}$ of Canarana, $13^{\circ} 35^{\prime} 53^{\prime}$ 'S 52 ${ }^{\circ} 15^{\prime} 35^{\prime \prime} \mathrm{W}$. MZUSP 94214, 21, 12.2 $16.6 \mathrm{~mm} \mathrm{SL}$, Campinápolis, rio Culuene, downstream $\mathrm{PCH}$ 


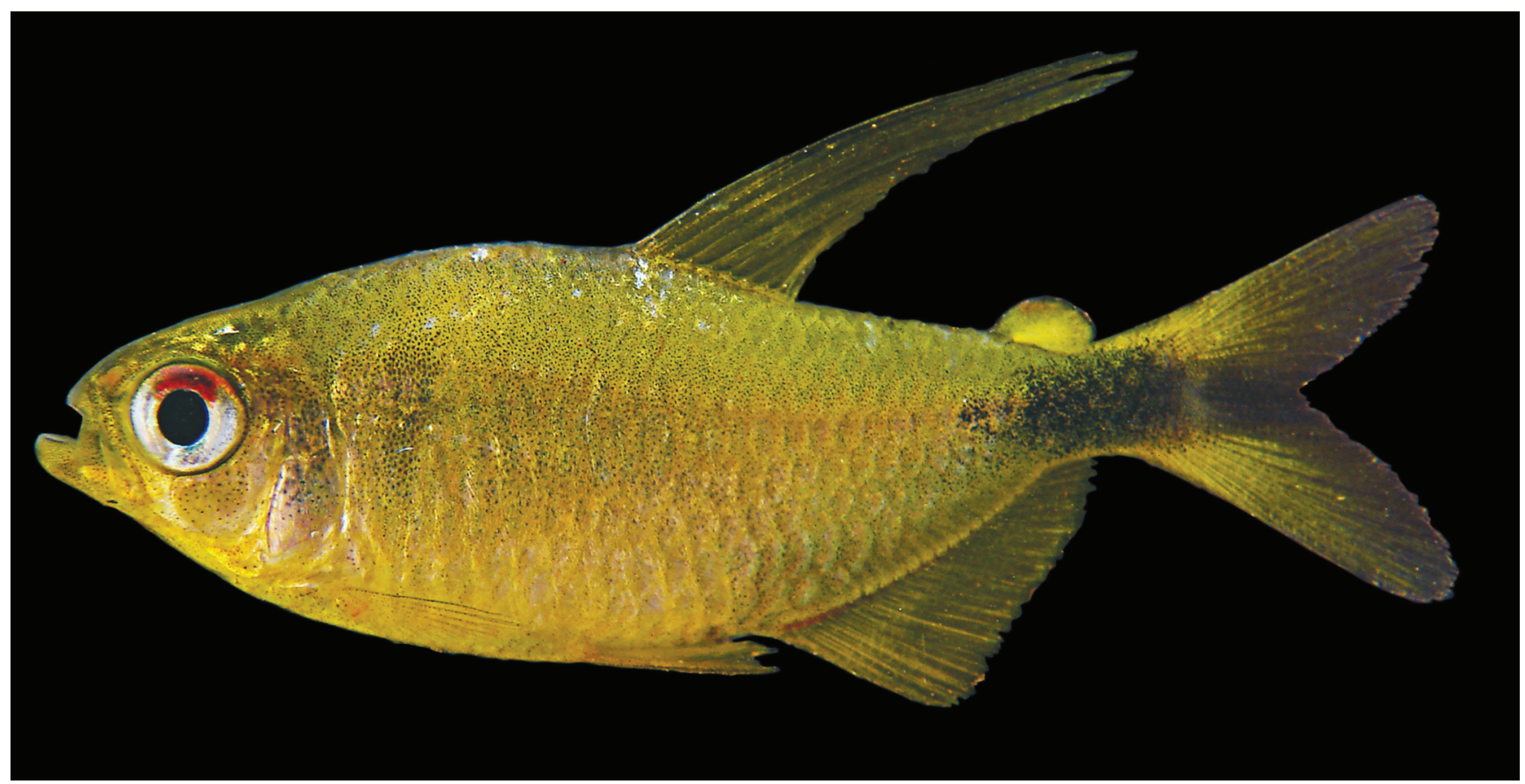

Fig. 9. Live specimen of Hyphessobrycon loweae, MZUSP 97435, 27.6 mm SL, male, Brazil, Mato Grosso State, rio Culuene basin.

Paranatinga II, $13^{\circ} 49^{\prime}$ S $53^{\circ} 15^{\prime}$ W. MZUSP 97846, 179, 17.4-30.8 $\mathrm{mm}$ SL, Primavera do Leste, córrego Xavante (tributary of rio Culuene), near road MT-130, 14³8'23'S 535'37'W. MZUSP 102816, 20, 21.2-34.2 mm SL, Paranatinga, córrego Xavante, tributary of rio Culuene, ca. $23 \mathrm{~km}$ from Paranatinga, road MT-130, $14^{\circ} 43^{\prime} 5^{\prime \prime} \mathrm{S} 54^{\circ} 04^{\prime} 37^{\prime \prime} \mathrm{W}$.

\section{Discussion}

As remarked in the Introduction, the genus Hyphessobrycon does not constitute a monophyletic entity. Pending further studies on the phylogenetic relationships of Hyphessobrycon and related genera, the new species described herein is provisionally assigned to this genus, following the traditional diagnosis of the genus. Based on the color pattern, Géry (1977) distinguished six admittedly artificial species groups within the genus. One of these groups, referred to as "Hyphessobrycon callistus-group" by Géry (1977), partly corresponds to the "rosy tetra clade", hypothesized by Weitzman \& Palmer (1997) to be a monophyletic entity. Hyphessobrycon loweae was listed among the species considered by Weitzman \& Palmer (1997: 223) as being "possible rosy tetras", probably due to the elongation of the dorsal fin in mature males, a feature shared with some species of the group, such as H. bentosi (Durbin), H. epicharis Weitzman \& Palmer, and H. erythrostigma (Fowler) (Weitzman \& Palmer, 1997). However, the elongation of the dorsal fin in $H$. loweae, as well as in $H$. elachys, $H$. heliacus, and $H$. peugeoti is formed by the extreme extension of the last unbranched, and two or three anteriormost branched dorsal-fin rays, forming a filamentous prolongation in fully mature males. This contrasts with the condition found in species belonging to the rosy tetra clade, such as $H$. bentosi, $H$. epicharis, and $H$. erythrostigma, in which the last unbranched and the anteriormost four branched dorsal-fin rays, though elongated, are not considerably longer than the remaining dorsal-fin rays, and are not long enough to form a filamentous prolongation (Weitzman, 1977; Weitzman \& Palmer, 1997). Although Moreira, Landim \& Costa (2002: 431) stated that $H$. loweae does not possess a filamentous dorsal fin, fully mature males of the species do have this condition (Figs. 6 and 9). We consider this condition as nonhomologous to that found in $H$. erythrostigma and related species within the "rosy tetra clade" and reject the hypothesis of a close relationship between $H$. loweae and the species of that clade.

In most species of Hyphessobrycon and other tetras the posteriormost unbranched and the anteriormost branched anal-fin rays are more elongate than the remaining rays, forming a pointed, generally short, anterior fin lobe. The anal-fin rays of mature males of a few species of Hyphessobrycon, however, have approximately the same size, forming a straight margin. Within the genus this unusual condition is only known in $H$. bifasciatus, $H$. heliacus, $H$. loweae, and $H$. peugeoti. Mature males of $H$. bifasciatus are distinct in possessing numerous small hooks along the anal-fin rays. Hooks are absent in $H$. heliacus, $H$. loweae, and $H$. peugeoti mature males, suggesting that $H$. bifasciatus is closely related to other tetras with sexual hooks in the anal fin. In fact, in Mirande's (2010) phylogenetic hypothesis of the family Characidae, $H$. bifasciatus belongs to the Hyphessobrycon luetkenii 
clade and is closely related to the Astyanax clade, both clades composed almost exclusively by species displaying bony fin hooks. Mature males of $H$. heliacus, $H$. loweae, and $H$. peugeoti share a large, elongated dark blotch on the caudal peduncle, which extends across most of caudal peduncle's surface, including its upper and lower portions in $H$. loweae and H. peugeoti. As remarked by Moreira, Landim \& Costa (2002), mature males of $H$. elachys also possess a similar broad dark blotch on the caudal peduncle, which typically extends into the middle caudal-fin rays. Hyphessobrycon elachys was considered by Moreira, Lima \& Costa (2002) as related to H. moniliger Moreira, Lima \& Costa due to the shared, derived condition of the anal fin in mature males, which presents a well-defined, rounded lobe formed by thickened anal-fin rays, and upwarddirected projections on the proximal portion of the anal-fin rays (Moreira, Lima \& Costa, 2002: 78-79, figs. 4-5). Hyphessobrycon moniliger also possesses a welldeveloped caudal peduncle blotch in mature males, though not as developed as in the aforementioned species (Moreira, Lima \& Costa, 2002: 78). In spite of the similarities of anal- and dorsal-fin morphology and caudal-peduncle pigmentation in mature males, Moreira, Landim \& Costa (2002: 431-432) considered that accepting the monophyly of a group encompassing $H$. elachys, $H$. heliacus, and $H$. loweae would be premature at that time and that more studies on the phylogenetic relationships of Hyphessobrycon were needed to adequately address the issue. Although we understand the reasoning which prompted that cautionary note, the sum of similarities of anal- and dorsal-fin morphology and caudal-peduncle pigmentation shared by mature males of $H$. elachys, $H$. heliacus, $H$. loweae, $H$. moniliger, and $H$. peugeoti suggests a close relationship among these species.

Hemigrammus filamentosus Zarske was described from specimens from the aquarium hobby said to have been collected at the rio Araguaia basin in Brazil. Hemigrammus filamentosus is distinctive in possessing the first anal-fin rays elongated, a feature not observed in any of the aforementioned species. Zarske (2011) considered He. filamentosus as possibly related to He. taphorni Benine \& Lopes, due to the elongation of the dorsal fin in the latter. However, the elongation of the dorsal fin in He. taphorni apparently does not present the ribbon-like aspect present in He. filamentosus, Hyphessobrycon elachys, Hy. heliacus, Hy. loweae, and Hy. peugeoti, although this is an inference since the dorsal fin of the holotype of He. taphorni is not perfectly preserved (Benine \& Lopes, 2007: fig. 1). On the other hand, the dorsal fin in mature males of He. filamentosus is as elongate as in $\mathrm{Hy}$. elachys, Hy. heliacus, Hy. loweae, and Hy. peugeoti, and the pelvic fins are elongated and similar to the pelvic fins of $H y$. elachys and Hy. heliacus. Hemigrammus filamentosus and, perhaps, He. taphorni may belong to a monophyletic clade encompassing species currently assigned to the genera Hyphessobrycon and Hemigrammus, possessing sexually dimorphic males with modified fins. A proper evaluation of this hypothesis, however, will have to await a broader phylogenetic analysis encompassing species currently assigned to Hyphessobrycon, Hemigrammus and related genera, a task which has become more feasible after the recent publication of a phylogenetic analysis of the Characidae by Mirande (2010).

Comparative material examined. Brazil. Hyphessobrycon bifasciatus: São Paulo State: MZUSP 103202, 35, 24.2-42.1 mm SL, rio Tietê drainage. MZUSP 88245, 59, 25.8-43.0 mm SL, rio Tietê drainage. MZUSP 69588, 157, 25.4-38.4 mm SL, rio Juquiá. Hyphessobrycon elachys: Mato Grosso state: MZUSP 90508, 7, 11.9-19.3 mm SL, rio Jauru. MZUSP 90561, 16, 13.3-17.3 mm SL, rio Jauru. MZUSP 96661, 8, 12.0-14.7 mm SL, rio Cuiabá drainage. MZUSP 75378, 807, 11.7-15.2 mm SL, rio Itiquira drainage. Mato Grosso do Sul State: MZUSP 36305, 30, 11.9-17.1 mm SL, Nhecolândia. Hyphessobrycon heliacus: Mato Grosso State: MZUSP 18663, 12, 16.2-25.4 mm SL, rio Peixoto de Azevedo. MZUSP 99264, 14, 22.1-26.8 mm SL, rio Apiacás. MZUSP 98913, 1, 24.6 mm SL, rio Teles Pires drainage. MZUSP 42455, 1, $34.6 \mathrm{~mm}$ SL, rio Juína. Hyphessobrycon moniliger: Mato Grosso State: MZUSP 91170, 12, 22.0-30.8 mm SL; MZUSP 91194, 9, 22.2$27.8 \mathrm{~mm}$ SL, rio Sete de Setembro drainage. MZUSP 98439, 39, 16.1-21.8 mm SL, rio Teles Pires. Goiás State: MZUSP 89150, 10, 11.1-25.7 mm SL, rio Araguaia basin.

\section{Acknowledgments}

Type material of Hyphessobrycon peugeoti was collected during a field trip funded by Office National des Forêts Brasil (ONF Brasil) and PSA Peugeot/Citröen as part of the Peugeot/ONF Carbon Sink project. Material of Hyphessobrycon loweae was collected in expeditions funded by Pronex (FINEP and CNPq proc. 601058/1997-2 to N.A. Menezes), All Catfishes Species Inventory (NSF DEB0315663), and Atiaia Energia S/A. For help with fieldwork, we are grateful to Itamar L. Assumpção, Gilberto A. Araújo, Francisco A. Machado, Cristiano R. Moreira, Alexandre C. Ribeiro, Célia M. C. Leite, Nilso E. Silva, Lício Moraes, José L. Birindelli, and Carlos A. Figueiredo. Eduardo G. Baena photographed the specimens in Figs. 1, 2, 6, 7, and 8, and edited Fig. 4. José L. Birindelli prepared Fig. 5. Alexandre C. Ribeiro photographed the specimen in Fig. 9. We are grateful to Túlio F. Teixeira for discussions concerning Hyphessobrycon taxonomy and relationships, and for preparing Fig. 3. The authors are thankful to Juan M. Mirande and three anonymous reviewers for suggestions for the improvement of the manuscript. The authors were financially supported by Conselho Nacional de Desenvolvimento Científico e Tecnológico (CNPq proc. 474788/2006-7, 502975/ 2005-9, 308535/2009-0 to PAB; CNPq proc. 350672/2011-3, post-doctoral -DCR- fellowship to LFSI), Coordenação de Aperfeiçoamento de Pessoal de Nível Superior (CAPES, doctoral fellowship to LFSI), Fundação Estadual de Amparo à Pesquisa do Estado do Espírito Santo (FAPES proc. 53132203/2011, post-doctoral - DCR - fellowship to LFSI) and Fundação de Amparo à Pesquisa do Estado de São Paulo (FAPESP proc. 07/02978-7 to FCTL). 


\section{Literature Cited}

Almirón, A. E., J. R. Casciotta, J. A. Bechara. \& F. J. Ruiz Diaz. 2004. A new species of Hyphessobrycon (Characiformes, Characidae) from the Esteros del Iberá wetlands, Argentina. Revue suisse de Zoologie, 111: 673-682.

Almirón, A. E., J. E. Casciotta \& S. Körber. 2006. A new Hyphessobrycon (Characiformes, Characidae) from the río Uruguay basin, Argentina. Revue suisse de Zoologie, 113: 889896.

Benine, R. C. \& G. A. Lopes. 2007. A new species of Hemigrammus Gill, 1858 (Characiformes: Characidae) from Río Caura, Venezuela. Zootaxa, 1610: 53-59.

Bertaco, V. A. \& T. P. Carvalho. 2005. A new characid fish, Hyphessobrycon hexastichos (Characiformes: Characidae) from Chapada dos Parecis, Mato Grosso, Brazil. Neotropical Ichthyology, 3: 439-443.

Bertaco, V. A. \& L. R. Malabarba. 2005. A new species of Hyphessobrycon (Teleostei: Characidae) from the upper rio Tocantins drainage, with bony hooks on fins. Neotropical Ichthyology, 3: 83-88.

Bertaco, V. A., L. R. Malabarba \& J. Dergam. 2007. New Hyphessobrycon from the upper rio Pardo drainage in eastern Brazil (Teleostei: Characiformes: Characidae). Neotropical Ichthyology, 5: 245-250.

Carvalho, F. R., F. Langeani, C. S. Miyazawa \& W. P. Troy. 2008. Hyphessobrycon rutiliflavidus $\mathrm{n}$. sp., a new characid fish from the upper rio Paraguai, State of Mato Grosso, Brazil (Characiformes: Characidae). Zootaxa, 1674: 39-49.

Carvalho, T. P. \& V. A. Bertaco. 2006. Two new species of Hyphessobrycon (Teleostei: Characidae) from upper rio Tapajós basin on Chapada dos Parecis, Central Brazil. Neotropical Ichthyology, 4: 301-308.

Cockerell, T. D. A. 1915. The scales of the South American characinid fishes. Annals of the Carnegie Museum, 9: 92-113, pls. 23-28.

Costa, W. J. E. M. \& J. Géry. 1994. Two new species of the genus Hyphessobrycon (Characiformes: Characidae) from the rio Xingú basin, central Brazil. Revue Française d'Aquariologie, 20: 71-76.

Eigenmann, C. H. 1918. The American Characidae [part 2]. Memoirs of the Carnegie Museum, 43: 103-208.

Fink, S. V. \& W. L. Fink. 1981. Interrelationships of the ostariophysan fishes (Teleostei). Zoological Journal of the Linnean Society, 72: 297-353.

Fink, W. L. \& S. H. Weitzman. 1974. The so-called cheirodontin fishes of Central America with description of two new species (Pisces: Characidae). Smithsonian Contributions to Zoology, 172: $1-46$.

García-Alzate, C. A. \& C. Román-Valencia. 2008. Hyphessobrycon ocasoensis sp.n. (Teleostei, Characidae) una nueva especie para el Alto Cauca, Colombia. Animal Biodiversity and Conservation, 31: 11-23.

García-Alzate, C. A., C. Román-Valencia \& D. C. Taphorn. 2008a. Hyphessobrycon oritoensis (Characiformes: Characidae), a new species from the Putumayo River drainage, Colombian Amazon. Zootaxa, 1813: 42-50.

García-Alzate, C. A., C. Román-Valencia \& D. C. Taphorn. 2008b. Revision of the Hyphessobrycon heterorhabdus-group (Teleostei: Characiformes: Characidae), with description of two new species from Venezuela. Vertebrate Zoology, 58: 139-157.

García-Alzate, C. A., C. Román-Valencia \& D. C. Taphorn. 2010a. A new species of Hyphessobrycon (Teleostei: Characiformes:
Characidae) from the San Juan river drainage, Pacific versant of Colombia. Zootaxa, 2349: 55-64.

García-Alzate, C. A., C. Román-Valencia \& D. C. Taphorn. 2010 b. Two new species of Hyphessobrycon (Pisces: Characiformes: Characidae) from Putumayo River, with keys to the Colombian Hyphessobrycon heterorhabdus-group species. Brenesia, 70: 33-46 (date of publication incorrectly indicated as being 2008 in the article).

García-Alzate, C. A., C. Román-Valencia \& S. Prada-Pedreros. 2010c. Tres nuevas especies de Hyphessobrycon grupo heterorhabdus (Teleostei: Characiformes: Characidae), y clave para especies de la cuenca del Río Orinoco. Caldasia, 32: 443-461.

Géry, J. 1977. Characoids of the world. New Jersey, T. F. H. Publications, 672p.

Géry, J. \& J. Delage. 1963. Origine pathologique du stratum argenteum chez certaines variétés phénotypiques de Characidae, les "Brass-Tetras". Vie et Milieu, 14: 169-182.

Hein, G. 2009. Hyphessobrycon pando sp. n., a new rosy tetra from northern Bolivia (Teleostei, Characiformes, Characidae). Bulletin of Fish Biology, 10: 1-10.

Lima, F. C. T. \& P. Gerhard. 2001. A new Hyphessobrycon (Characiformes: Characidae) from Chapada Diamantina, Bahia, Brazil, with notes on its natural history. Ichthyological Exploration of Freshwaters, 12: 105-114.

Lima, F. C. T., L. R. Malabarba, P. A. Buckup, J. F. Pezzi da Silva, R. P. Vari, A. Harold, R. C. Benine, O. T. Oyakawa, C. S. Pavanelli, N. A. Menezes, C. A. S. Lucena, R. E. Reis, F. Langeani, L. Casatti, V. A. Bertaco, C. R. Moreira \& P. H. F. Lucinda. 2003. Genera incertae sedis in Characidae. Pp. 106-169. In: Reis, R. E., S. O. Kullander \& C. J. Ferraris (Eds.). Check List of the freshwater fishes of South and Central America. Edipucrs, Porto Alegre, 729p.

Lima, F. C. T. \& C. R. Moreira. 2003. Three new species of Hyphessobrycon (Characiformes: Characidae) from the upper rio Araguaia basin in Brazil. Neotropical Ichthyology, 1: 21-33.

Lima, F. C. T. \& A. C. Ribeiro. 2011. Continental-scale tectonic controls of biogeography and ecology. Pp. 145-164. In: Albert, J. S. \& R. E. Reis (Eds.). Historical Biogeography of Neotropical Freshwater Fishes. University of California Press, Berkeley, 408p.

Lima, S. M. Q., A. A. Cunha, J. I. Sánchez-Botero \& E. P. Caramaschi. 2008. Vertical segregation of two species of Hyphessobrycon (Characiformes: Characidae) in the Cabiúnas coastal lagoon, southeastern Brazil. Neotropical Ichthyology, 6: 683-688.

Lowe-McConnell, R. H. 1991. Natural history of fishes in Araguaia and Xingu Amazonian tributaries, Serra do Roncador, Mato Grosso, Brazil. Ichthyological Exploration of Freshwaters, 2: 63-82.

Lucena, C. A. S. 2003. New characid fish, Hyphessobrycon scutulatus, from the rio Teles Pires drainage, upper rio Tapajós system (Ostariophysi: Characiformes: Characidae). Neotropical Ichthyology, 1: 93-96.

Malabarba, L. R., V. A. Bertaco, F. R. Carvalho \& T. O. Litz. 2012. Revalidation of the genus Ectrepopterus (Teleostei: Characiformes), with the description of its type species, $E$. uruguayensis. Zootaxa, 3204: 47-60.

Malabarba, L. R. \& S. H. Weitzman. 2003. Description of a new genus with six new species from southern Brazil, Uruguay and Argentina, with a discussion of a putative characid clade (Teleostei: Characiformes: Characidae). Comunicações do Museu de Ciências da PUCRS, série Zoologia, 16: 67-151.

Menezes, N. A. \& S. H. Weitzman. 1990. Two new species of Mimagoniates (Teleostei: Characidae: Glandulocaudinae), their 
phylogeny and biogeography and a key to the glandulocaudin fishes of Brazil and Paraguay. Proceedings of the Biological Society of Washington, 103: 380-426.

Menezes, N. A. \& S. H. Weitzman. 2009. Systematics of the Neotropical fish subfamily Glandulocaudinae (Teleostei: Characiformes: Characidae). Neotropical Ichthyology, 7: 295370 .

Miquelarena, A. M. \& H. L. López. 2006. Hyphessobrycon togoi, a new species from the La Plata basin (Teleostei: Characidae) and comments about the distribution of the genus in Argentina. Revue suisse de Zoologie, 113: 817-828.

Miquelarena, A. M. \& H. L. López. 2010. Hyphessobrycon nicolasi (Teleostei: Characidae) a new species from the Uruguay River basin in the Mesopotamian region, Argentina. Neotropical Ichthyology, 8: 1-6.

Mirande, J. M. 2010. Phylogeny of the family Characidae (Teleostei: Characiformes): from characters to taxonomy. Neotropical Ichthyology, 8: 385-568.

Moreira, C. R., M. I. Landim \& W. J. E. M. Costa. 2002. Hyphessobrycon heliacus: a new characid fish (Ostariophysi: Characiformes) from the upper rio Tapajós basin, Central Brazil. Copeia, 2002: 428-432.

Moreira, C. R., F. C. T. Lima \& W. J. E. M. Costa. 2002. Hyphessobrycon moniliger, a new characid fish from rio Tocantins basin, Central Brazil (Ostariophysi: Characiformes). Ichthyological Exploration of Freshwaters, 13: 73-80.

Taylor, W. R. \& G. C. van Dyke. 1985. Revised procedures for staining and clearing small fishes and other vertebrates for bone and cartilage study. Cybium, 9: 107-109.

Weitzman, S. H. 1977. Hyphessobrycon socolofi, a new species of characoid fish (Teleostei: Characidae) from the Rio Negro of Brazil. Proceedings of the Biological Society of Washington, 90: 326-347.
Weitzman, S. H. \& W. L. Fink. 1983. Relationships of the neon tetras, a group of South American freshwater fishes (Teleostei, Characidae), with comments on the phylogeny of New World characiforms. Bulletin of the Museum of Comparative Zoology, 150: 339-395.

Weitzman, S. H. \& L. Palmer. 1997. A new species of Hyphessobrycon (Teleostei: Characidae) from the Neblina region of Venezuela and Brazil, with comments on the putative 'rosy tetra clade'. Ichthyological Exploration of Freshwaters, 7: 209-242.

Zanata, A. M. \& P. Camelier. 2010. Hyphessobrycon brumado: a new characid fish (Ostariophysi: Characiformes) from the upper rio de Contas drainage, Chapada Diamantina, Bahia, Brazil. Neotropical Ichthyology, 8: 771-777.

Zarske, A. 2008. Hyphessobrycon khardinae sp.n. - ein neuer Blutsalmler aus Brasilien (Teleostei: Characiformes: Characidae) Vertebrate Zoology, 58: 5-13.

Zarske, A. 2011. Hemigrammus filamentosus spec. nov. - der Südamerikanische Fadensalmler, ein neuer Salmler (Teleostei: Characiformes: Characidae) aus dem Araguaya-Becken in Brasilien. Vertebrate Zoology, 61: 3-12.

Zarske, A. \& J. Géry. 2004. Hyphessobrycon nigricinctus sp.n. ein neuer Salmler (Teleostei: Characiformes: Characidae) aus dem Stromgebiet des río Madre de Dios in Peru. Zoologische Abhandlungen, 54: 31-38.

Zarske, A. \& J. Géry. 2006. Beschreibung einer neuen SalmlerGattung und zweier neuer Arten (Teleostei: Characiformes: Characidae) aus Peru und Brasilien. Zoologische Abhandlungen, 55: $1-39$

Zarske, A., P. -Y. Le Bail \& J. Géry. 2006. New and poorly known Characiform fishes from French Guiana. 1. Two new tetras of the genera Hemigrammus and Hyphessobrycon (Teleostei: Characiformes: Characidae). Zoologische Abhandlungen, 55 17-30.

Submitted August 21, 2011

Accepted September 27, 2012 by Paulo H. F. Lucinda

Published March 31, 2013 